\title{
PEMBERIAN MAKANAN TAMBAHAN SEBAGAI UPAYA PENANGANAN STUNTING PADA BALITA DI INDONESIA
}

\author{
Yuni Khoirul Waroh \\ Dosen Universitas PGRI Adi Buana Surabaya, Jl. Dukuh Menanggal XII Surabaya \\ Email: yunikhoirulwaroh@unipasby.ac.id
}

\begin{abstract}
ABSTRAK
Stunting (kerdil) adalah kondisi dimana balita memiliki panjang atau tinggi badan yang kurang jika dibandingkan dengan umur. Kondisi ini diukur dengan panjang atau tinggi badan yang lebih dari minus dua standar deviasi median standar pertumbuhan anak dari WHO. Balita stunting termasuk masalah gizi kronik yang disebabkan oleh banyak faktor seperti kondisi sosial ekonomi, gizi ibu saat hamil, kesakitan pada bayi, dan kurangnya asupan gizi pada bayi. Balita stunting di masa yang akan datang akan mengalami kesulitan dalam mencapai perkembangan fisik dan kognitif yang optimal. Hasil Riset Kesehatan Dasar (Riskesdas) tahun 2007 menunjukkan prevalensi balita pendek di Indonesia sebesar $36,8 \%$. Pada tahun 2010 , terjadi sedikit penurunan menjadi 35,6\%. Namun prevalensi balita pendek kembali meningkat pada tahun 2013 yaitu menjadi 37,2\%. Prevalensi balita pendek Riskesdas tahun 2018 terjadi sedikit penurunan menjadi 30,8\%. Berdasarkan Peraturan Menteri Kesehatan Nomor 39 Tahun 2016 tentang Pedoman Penyelenggaraan Program Indonesia Sehat dengan Pendekatan Keluarga, upaya yang dilakukan untuk menurunkan prevalensi stunting pada balita adalah dengan menyelenggarakan program Pemberian Makanan Tambahan (PMT). Yang dimana dengan Pemberian Makanan Tambahan akan menurunkan angka kejadian stunting pada balita.
\end{abstract}

Kata Kunci: Stunting, PMT, Balita, Indonesia

\begin{abstract}
Stunting (dwarf) is a condition where toddlers have a length or height that is less than age. This condition is measured by length or height which is more than minus two median standard deviations of the child growth standard of the WHO. Stunting toddlers include chronic nutrition problems caused by many factors such as socio-economic conditions, maternal nutrition during pregnancy, pain in infants, and lack of nutritional intake in infants. Stunting toddlers in the future will experience difficulties in achieving optimal physical and cognitive development. The results of the Basic Health Research (Riskesdas) in 2007 showed that the prevalence of short toddlers in Indonesia was $36.8 \%$. In 2010, there was a slight decrease to $35.6 \%$. However, the prevalence of short toddlers again increased in 2013, which was $37.2 \%$. The prevalence of children under five in Riskesdas in 2018 decreased slightly to 30.8\%. Based on the Minister of Health Regulation No. 39 of 2016 concerning the Guidelines for Implementing a Healthy Indonesia Program with a Family Approach, efforts made to reduce the prevalence of stunting in children under five are by organizing a supplementary feeding program (PMT). Which is where the Supplemental Feeding will reduce the incidence of stunting in infants
\end{abstract}

Keywords: Stunting, PMT, Toddler, Indonesian 


\section{PENDAHULUAN}

Stunting (kerdil) adalah kondisi dimana balita memiliki panjang atau tinggi badan yang kurang jika dibandingkan dengan umur. Kondisi ini diukur dengan panjang atau tinggi badan yang lebih dari minus dua standar deviasi median standar pertumbuhan anak dari WHO (Data dan Informasi Kesehatan Indonesia, 2018).

Data prevalensi balita stunting yang dikumpulkan World Health Organization (WHO), Indonesia termasuk ke dalam negara ketiga dengan prevalensi tertinggi di regional Asia Tenggara/South-East Asia Regional (SEAR). Rata-rata prevalensi balita stunting di Indonesia tahun 20052017 adalah 36,4\% (Pusat Data dan Informasi, 2018).

Kejadian balita stunting (pendek) merupakan masalah gizi utama yang dihadapi Indonesia. Berdasarkan data Pemantauan Status Gizi (PSG) selama tiga tahun terakhir, pendek memiliki prevalensi tertinggi dibandingkan dengan masalah gizi lainnya seperti gizi kurang, kurus, dan gemuk. Prevalensi balita pendek mengalami peningkatan dari tahun 2016 yaitu 27,5\% menjadi 29,6\% pada tahun 2017 (Kementerian Desa, 2017).

Prevalensi balita pendek di Indonesia cenderung statis. Hasil Riset Kesehatan Dasar (Riskesdas) tahun 2007 menunjukkan prevalensi balita pendek di Indonesia sebesar 36,8\%. Pada tahun 2010, terjadi sedikit penurunan menjadi $35,6 \%$. Namun prevalensi balita pendek kembali meningkat pada tahun 2013 yaitu menjadi $37,2 \%$. Prevalensi balita pendek Riskesdas tahun 2018 terjadi sedikit penurunan menjadi 30,8\% (Riskesdas, 2018).

Indonesia saat ini tengah dihadapkan pada "double burden of malnutrition" atau masalah gizi ganda dimana pada satu sisi masih harus berupaya keras untuk mengatasi masalah kekurangan gizi salah satunya stunting, sementara di sisi lain masalah kelebihan gizi mulai merangkak naik yang berujung pada peningkatan kasus penyakit tidak menular (PTM) pada kelompok dewasa. Berinvestasi melalui pemenuhan gizi mutlak diperlukan sebagai bagian dari rumusan perencanaan pembangunan sebuah negara. Mendapat asupan gizi yang cukup adalah hak asasi yang selayaknya didapatkan oleh setiap individu. Gizi yang cukup dapat menunjang lebih optimal pertumbuhan dan perkembangan sejak janin hingga tahapan kehidupan selanjutnya. Pada jangka panjang pemenuhan kebutuhan gizi dapat memperbaiki kualitas generasi selanjutnya, dimana secara tidak langsung akan meningkatkan manfaat ekonomi yang signifikan melalui perbaikan kualitas sumber daya manusia (Ditjen Kesehatan Masyarakat, 2017).

Salah satu solusi dalam penanganan stunting pada balita adalah dengan melakukan Pemberian Makanan Tambahan (PMT) (Permenkes Republik 
Indonesia Nomor 51 Tahun 2016). Prevalensi balita 6-59 bulan di Indonesia yang mendapat Pemberian Makanan Tambahan (PMT) tahun 2018 sebesar $41 \%$.

\section{METODE}

Metode yang digunakan yakni pencarian hasil peneltian maupun artikel menggunakan Google Scolar. Kata kunci yang digunakan antara lain "Stunting", "PMT", "Balita".

\section{PEMBAHASAN}
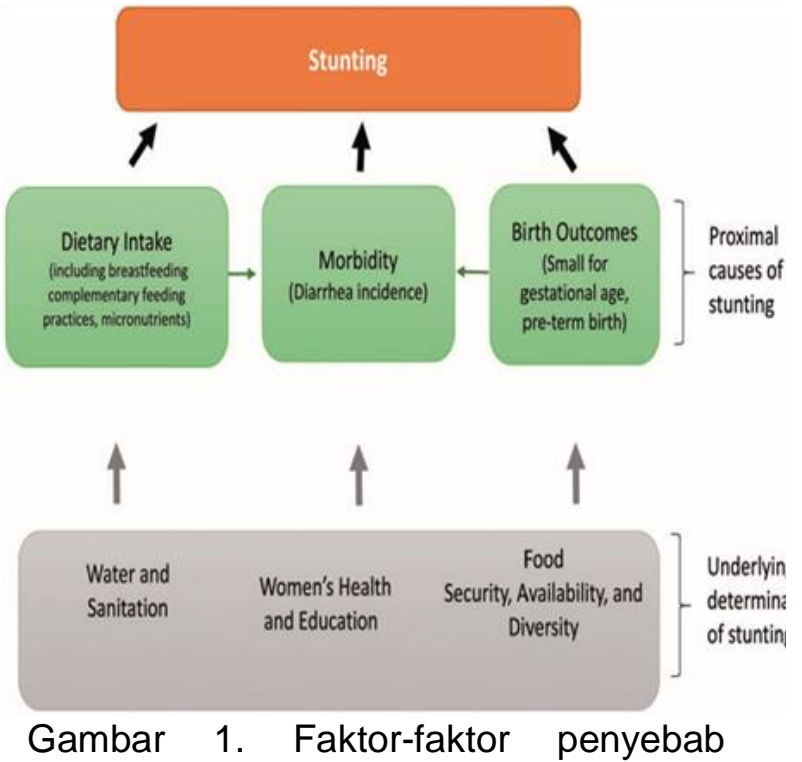
stunting

Menurut Meera Shekar, et al (2018) faktor yang paling banyak menyebabkan stunting adalah dari pemenuhan nutrisi sesuai dengan gambar 1 di atas..

Pemerintah Indonesia sudah mencanangkan sasaran pembangunan pangan dan gizi dalam RPJMN 2010-2014 dan RAN-PG 2011-2015 adalah menurunkan prevalensi kekurangan gizi pada balita, termasuk stunting. Beberapa program dan kegiatan pembangunan nasional telah dilakukan untuk mendukung sasaran tersebut. Seiring dengan hal tersebut, gerakan perbaikan gizi dengan fokus terhadap kelompok 1000 hari pertama kehidupan pada tataran global disebut Scaling Up Nutrition (SUN) dan di Indonesia disebut dengan Gerakan Nasional Percepatan Perbaikan Gizi dalam Rangka 1000 Hari Pertama Kehidupan (Gerakan 1000 HPK) (Nilfar,Ruanida, 2018).

SUN (Scaling Up Nutrition) Movement merupakan upaya global dari berbagai negara dalam rangka memperkuat komitmen dan rencana aksi percepatan perbaikan gizi, khususnya penanganan gizi sejak 1.000 hari dari masa kehamilan hingga anak usia 2 tahun. Gerakan ini merupakan respon negara-negara di dunia terhadap kondisi status gizi disebagian besar negara berkembang dan akibat kemajuan yang tidak merata dalam mencapai Tujuan Pembangunan Milenium/MDGs (Nilfar, Ruanida, 2018).

Pemberian Makanan Tambahan (PMT) adalah upaya memberikan tambahan makanan untuk menambah asupan gizi untuk mencukupi kebutuhan gizi agar tercapainya status gizi yang baik (Permenkes Republik Indonesia Nomor 51 Tahun 2016).

Makanan tambahan yang diberikan dapat berbentuk makanan keluarga 
berbasis pangan lokal dengan resepresep yang dianjurkan. Makanan lokal lebih bervariasi namun metode dan lamanya memasak sangat menentukan ketersediaan zat gizi yang terkandung di dalamnya (Permenkes Republik Indonesia No 51 Tahun 2016).

Suplementasi gizi dapat juga diberikan berupa makanan tambahan pabrikan, yang lebih praktis dan lebih terjamin komposisi zat

gizinya. Pemberian makanan tambahan yang ditujukan untuk kelompok rawan meliputi balita 6-24 bulan dengan kategori kurus yaitu balita dengan hasil pengukuran berat badan menurut panjang badan (BB/PB) lebih kecil dari minus dua Standar Deviasi (-2 SD), anak usia sekolah dasar dengan kategori kurus, dan ibu hamil kurang energi kronis yaitu ibu hamil dengan hasil pengukuran Lingkar Lengan Atas (LiLA) lebih kecil dari 23,5 cm (Permenkes,RI, 2016). Lama pemberian idealnya 180 hari (2 hari sekali).

Standar Makanan Tambahan untuk Balita 6-59 bulan dengan kategori:

\section{A. Kandungan}

1. Komposisi

Produk berbentuk biskuit yang terbuat dari campuran terigu, isolat protein, susu, lemak nabati yang tidak dihidrogenasi, sukrosa, diperkaya vitamin dan mineral, dengan atau tanpa penambahan Bahan Tambahan Pangan (BTP) sesuai dengan ketentuan yang berlaku. Semua bahan yang digunakan harus bermutu, bersih, aman, dan sesuai untuk dikonsumsi balita usia 6-59 bulan (Permenkes Republik Indonesia Nomor 51 Tahun 2016).

\section{Syarat Mutu}

Zat gizi yang terkandung dalam 100 gram produk harus memenuhi persyaratan mutu sesuai dengan tabel 1 di bawah.

Tabel 1. Syarat Mutu Zat Gizi Yang Terkandung Dalam 100 Gram Produk

\begin{tabular}{|c|c|c|c|}
\hline No & Zat Gizi & Satuan & Kadar \\
\hline 1 & Energi & kkal & Minimum 400 \\
\hline 2 & 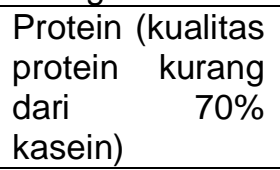 & $\mathrm{g}$ & $8-12$ \\
\hline 3 & Lemak & $g$ & $10-18$ \\
\hline & $\begin{array}{l}\text { Asam Linolenat } \\
\text { (Omega 3) }\end{array}$ & $g$ & $0,4-0,6$ \\
\hline & $\begin{array}{l}\text { Asam Linoleat } \\
\text { (Omega 6) }\end{array}$ & g & $1,7-2,9$ \\
\hline 4 & Karbohidrat & & \\
\hline & 4.1 Serat & $g$ & Maksimum 5 \\
\hline & 4.2 Sukrosa & g & Maksimum 20 \\
\hline 5 & Vitamin $A^{*}$ & $\mathrm{mcg}$ & $200-400$ \\
\hline 6 & Vitamin D & $\mathrm{mcg}$ & $5-10$ \\
\hline 7 & Vitamin E & $\mathrm{mg}$ & $3-6$ \\
\hline 8 & Vitamin $\mathrm{K}$ & $\mathrm{mcg}$ & $4-6$ \\
\hline 9 & $\begin{array}{ll}\begin{array}{l}\text { Vitamin } \\
\text { (Thiamin) }\end{array} & \text { B1 } \\
\end{array}$ & $\mathrm{mg}$ & $0,25-0,5$ \\
\hline 10 & $\begin{array}{ll}\text { Vitamin } & \text { B2 } \\
\text { (Riboflavin) } & \\
\end{array}$ & $\mathrm{mg}$ & $0,3-0,6$ \\
\hline 11 & $\begin{array}{ll}\text { Vitamin } & \text { B6 } \\
\text { (Pyridoksin) } & \\
\end{array}$ & $\mathrm{mg}$ & $0,2-0,4$ \\
\hline 12 & $\begin{array}{l}\text { Vitamin B12 } \\
\text { (Cobalamin) }\end{array}$ & $\mathrm{mcg}$ & $0,35-0,7$ \\
\hline 13 & $\begin{array}{ll}\begin{array}{l}\text { Vitamin } \\
\text { (Niasin) }\end{array} & \text { B3 } \\
\end{array}$ & $\mathrm{mg}$ & $2,5-5,0$ \\
\hline 14 & Folat & $\mathrm{mcg}$ & $60-120$ \\
\hline 15 & Besi ${ }^{\star *}$ & $\mathrm{mg}$ & $4,0-7,5$ \\
\hline 16 & lodium ${ }^{\star * \star}$ & $\mathrm{mcg}$ & $60-120$ \\
\hline 17 & Seng & $\mathrm{mg}$ & $\begin{array}{l}2,0-3,75 \\
\text { Perbandingan } \\
\text { Fe: } Z n=1,0- \\
2,0: 1\end{array}$ \\
\hline 18 & Kalsiumm**** & $\mathrm{mg}$ & $225-450$ \\
\hline
\end{tabular}




\begin{tabular}{|c|l|c|l|}
\hline 19 & Natrium & $\mathrm{mg}$ & $\begin{array}{l}\text { Maksimum } \\
300\end{array}$ \\
\hline 20 & Selenium & \\
\hline & & $\mathrm{mcg}$ & $7-14$ \\
\hline 21 & Fosfor & & $\begin{array}{l}180-275 \\
\text { Perbandingan }\end{array}$ \\
& & $\mathrm{mg}$ & $\begin{array}{l}180-275 \\
\text { Perbandingan } \\
\text { Ca:P=1,2-2,0: } \\
\end{array}$ \\
& & & 1 \\
\hline 22 & Fluor & \\
& & $\mathrm{mg}$ & $\begin{array}{l}\text { Maksimum } \\
0,25\end{array}$ \\
\hline 23 & Air & & Maksimum 5 \\
\hline
\end{tabular}

Keterangan :

*Vitamin A ditambahkan dalam bentuk retinil asetat

**Besi ditambahkan dalam bentuk senyawa ferro fumarat

*** Iodium ditambahkan dalam bentuk kalium iodat

${ }^{\star * * \star K}$ Kalsium ditambahkan dalam bentuk kalsium iodat

$\star \star \star \star \star$ Selenium yang ditambahkan dalam bentuk sodium selenite

${ }^{\star * \star \star * \star}$ Fluor idak boleh ditambahkan hanya bawaan dari bahan baku

B. Bahan Tambahan Pangan (BTP)

(Permenkes Republik Indonesia Nomor 51 Tahun 2016)

1. Penggunaan BTP harus sesuai dengan ketentuan peraturan perundang-undangan.

2. BTP yang diperbolehkan adalah pengemulsi, pengatur keasaman, antioksidan, pengembang, pengental, anti kempal, dan gas untuk kemasan. Perisa yang diperbolehkan adalah:

a. Ekstrak buah alami dan estrak vanilla: Cara Produksi Pangan yang Baik (CPPB); dan

b. Etil vanillin dan vanilin: maksimum $7 \mathrm{mg} / 100 \mathrm{~g}$.

3. Pewarna sintetik, pengawet dan pemanis buatan tidak boleh dipergunakan.

C. Cemaran memenuhi batas cemaran mikroba, logam berat, dan cemaran lain sesuai dengan ketentuan peraturan perundang-undangan

(Permenkes Republik Indonesia Nomor 51 Tahun 2016).

D. Pengolahan

1. Pengolahan produk dilakukan dengan menerapkan cara produksi pangan olahan yang baik sesuai dengan ketentuan peraturan perundang-undangan.

2. Proses pengolahan menggunakan teknologi industri guna memperoleh produk berkualitas (Permenkes Republik Indonesia Nomor 51 Tahun 2016).

E. Pengemasan dan Pelabelan

1. Produk dikemas sedemikian rupa untuk mempertahankan kualitas, keamanan, dan kemanfaatan produk.

2. Pelabelan dilakukan sesuai dengan ketentuan peraturan perundangundangan.

3. Ketentuan lain yang harus dicantumkan pada label sebagai berikut:

a) Peruntukan produk: "makanan tambahan untuk balita 6-59 bulan dengan kategori kurus"

b) Petunjuk penyajian bagi bayi usia 6-11 bulan dan anak balita usia 12-59 bulan.

c) Takaran saji dan anjuran konsumsi sehari, sesuai dengan pedoman yang ditetapkan oleh Menteri 


(Permenkes
Indonesia Nomor 51 Tahun
2016).

\section{Pengaruh Pemberian Makanan Tambahan Pemulihan (PMT-P) terhadap Status Gizi Balita Gizi Buruk} Menurut Farida Fitriyanti, Tatik Mulyati (2012) terdapat perbedaan status gizi berdasarkan BB/TB dan BB/U setelah pemberian PMT-P selama 60 hari. Hal ini disebabkan kontribusi asupan energi dan protein dari PMT-P yang diasup oleh balita mengalami peningkatan di setiap minggunya dan didukung dengan peningkatan asupan energi dan protein dari makanan selain PMT-P, sehingga tingkat asupan dalam sehari sebagian besar dapat terpenuhi. Rerata kontribusi energi dan protein pada PMT-P sebesar $54.60 \pm 26.04 \%$ dan $79.17 \pm 37.75 \%$ lebih besar dibandingkan dengan kontribusi asupan energi dan protein dari makanan selain PMT-P sebesar $49.09 \pm 27.42 \%$ dan $48.24 \pm 13.86 \%$.

Pemberian PMT-P dalam bentuk formula atau cair mengandung semua nutrisi yang diperlukan balita gizi buruk, ditambah dengan vitamin, mineral dengan osmolaritas yang rendah dan dalam porsi kecil sehingga memudahkan balita dalam mengkonsumsi dan penyerapan nutrisi. Formula ini mengandung lemak nabati, whey, gula kompleks, mineral dan vitamin sehingga cocok untuk fase transisi pada balita gizi buruk yang membutuhkan makanan yang padat gizi untuk memperbaiki jaringan tubuh yang rusak (catch up). PMT-P yang diberikan mengandung protein yang mempunyai kandungan semua jenis asam amino esensial dalam proporsi yang sesuai untuk pertumbuhan sehingga lebih mudah diserap oleh tubuh dan keseimbangan komposisis ini tepat untuk perbaikan jaringan tubuh yang rusak.

Lemak yang digunakan berupa lemak MCT yang mudah diabsorbsi dan dapat membantu meningkatkan penyerapan vitamin A, D, E, K. Lemak MCT cocok untuk balita gizi buruk yang proses pencernaan dan metaboliknya bermasalah karena pemecahan MCT sudah terjadi di rongga usus sehingga mengurangi penggunaan enzim lipase dari pankreas dan asam empedu sehingga penyerapan akan mudah meski dengan sedikit bantuan enzim. Sedangkan untuk kabohidrat berupa glukosa polimer (bebas laktosa) sehingga lebih mudah diabsorbsi oleh tubuh. Selain itu pada PMT-P juga mempunyai kandungan gizi berupa seng $(\mathrm{Zn})$, kalium, magnesium dan tembaga (Cu) yang dapat membantu dalam proses pertumbuhan balita. Seng (Zn), kalium, magnesium dan tembaga $(\mathrm{Cu})$ sangat dibutuhkan pada saat terjadi diare serta dehidrasi. 
Pada balita yang mengalami gizi buruk, penting untuk memperhatikan kepadatan nutrisi yang cukup dan seimbang agar fisiologis serta imunologi tubuh balita dapat kembali normal dan dapat meningkatkan berat badan. 9,29,30 Penelitian yang dilakukan oleh Collins S dkk pada balita gizi buruk di Ethiopia pada tahun 2005 dengan pemberian paket makanan terapi siap makan (RUTF) berbentuk pasta setara dengan F100 dengan kontribusi energi dan protein sebesar $75 \%$ dari kebutuhan sehari selama 3 bulan menunjukkan $85 \%$ balita status gizi nya dapat berubah dengan nilai z-score dari <-3SD menjadi >-2SD.22,23 (Fitriyanti, 2012).

Pemberian PMT-P merupakan tambahan makanan utama balita sasaran dan bukan merupakan makanan pengganti makanan sehari-hari balita sasaran. Adanya kenaikan berat badan tidak hanya karena pemberian PMT-P saja, namun ada faktor lain yang diduga juga turut meningkatkan berat badan balita sasaran program PMT-P, seperti konsumsi makanan utama balita (Supadmi dkk, 2008) dan konsumsi snack atau makanan selingan balita (Sugianti, E, 2017).

\section{KESIMPULAN}

Berdasarkan hasil studi pustaka yang dilakukan, dapat ditarik kesimpulan bahwa PMT-P memberikan pengaruh yang signifikan terhadap perubahan status gizi berdasarkan BB/TB dan BB/U balita gizi buruk dengan memberikan rerata kontribusi energi sebanyak $54.60 \pm 15.42 \%$ dan protein $79.17 \pm 37.75 \%$ dari kebutuhan seharusnya dalam sehari.

\section{DAFTAR PUSTAKA}

Fitriyanti, Farida dan Tatik Mulyati, 2012, Pengaruh Pemberian Makanan Tambahan Pemulihan (PMT-P) terhadap Status Gizi Balita Gizi Buruk di Dinas Kesehatan Kota Semarang, Journal of Nutrition College, Volume 1;373-381

Kementerian Desa, Pembangunan Daerah Tertinggal dan Transmigrasi, 2017, Buku Saku Desa dalam Penanganan Stunting, Edisi I, Jakarta

Kementerian Kesehatan, 2018, Hasil Utama Riskesdas 2018, Badan Penelitian dan Pengembangan Kesehatan, Jakarta

Meera Shekar, Jakub Kakietek, Mary R D'Alimonte, Hilary E Rogers,Julia Dayton Eberwein,Jon Kweku Akuoku,Audrey Pereira, Shan SoeLin and Robert Hecht, 2017, Reaching the global target to reduce stunting: an investment framework, Health Policy and Planing, 667-668

Nilfar Ruanida, 2018, Gerakan 1000 hari Pertama Kehidupan Mencegah Terjadinya Stunting (Gizi Pendek) di Indonesia, Global Health Science, Volume 3 No 2

Peraturan Menteri Kesehatan Republik Indonesia Nomor 51 Tahun 2016, Standar Produk Suplementasi Gizi, Lembaran Negara Republik Indonesia Tahun 2016 Nomor 1600, Jakarta

Pusat Data dan Informasi, 2018, Situasi Balita Pendek (Stunting) di Indonesia , Semester I, Buletin 
Jendela Data dan Informasi Kesehatan, Jakarta

Sugianti, E, 2017, Evaluasi pemberian Makanan Tambahan Pemulihan (PMT-P) pada Balita Kurang Gizi di Kabupaten Tuban, Jurnal Cakrawala, Volume 11:217-224

Supadmi dkk. 2008. Pengaruh Pemberian Makanan Tambahan pada Balita Kur ang Ene rg i Pro te in (KEP) Pengunjung Balai Penelitian dan Pengembangan Gangguan Akibat Kekurangan Yodium (BPP GAKY)

Magelang. PGM31(2): 59-66 